\title{
Employees' Satisfaction of Government Organization in Tangail City, Bangladesh
}

\author{
Sayed Mohibul Hossen ${ }^{1}$, Md. Takrib Hossain ${ }^{2}$, Md. Masud Rana ${ }^{2} \&$ Mohd Tahir Ismail $^{3}$ \\ ${ }^{1} \mathrm{PhD}$ student, School of Mathematical Sciences, Universiti Sains Malaysia, 11800 USM Penang, Malaysia. \\ Assistant Professor, Department of Statistics, Faculty of Science, Mawlana Bhashani Science and Technology \\ University, Tangail, Bangladesh. \\ ${ }^{2}$ Department of Statistics, Faculty of Science, Mawlana Bhashani Science and Technology University, Tangail, \\ Bangladesh \\ ${ }^{3}$ Associate Professor \& Deputy Dean, School of Mathematical Sciences, Universiti Sains Malaysia, 11800 USM \\ Penang, Malaysia \\ Correspondence: Sayed Mohibul Hossen, PhD student, School of Mathematical Sciences, Universiti Sains \\ Malaysia, 11800 USM Penang, Malaysia. Assistant Professor, Department of Statistics, Faculty of Science, \\ Mawlana Bhashani Science and Technology University, Tangail, Bangladesh.
}

Received: December 3, 2018

Accepted: December 28, 2018

Online Published: January 11, 2019

doi:10.5539/ibr.v12n2p15

URL: https://doi.org/10.5539/ibr.v12n2p15

\begin{abstract}
Employees' satisfaction is directly related to their commitment, citizenship behavior, turnover, absenteeism, dedication and performance. Job satisfaction is important to attract and retain talent workforce. Organization can ensure a competitive advantage over the key rivals through confirming the satisfaction of employees towards job. Organization need to meet the expectations of employees' which shall ensure their job satisfaction. The purpose of the study is to measure the job satisfaction in government employees of Tangail district. Primary data was used in the study and the sample size of the study was 80 . The study revealed the key facets of job satisfaction in government sector of Bangladesh. Factors including salary of employees, performance appraisal system, promotional strategies, employee's relationship with management and other co- employees, training and development program, work burden, influence of higher authority and working hours are found important for improving job satisfaction of govt. employees in Tangail city. Increase in level of these factors improves overall satisfaction of employees which is identified by using statistical technique.
\end{abstract}

Keywords: employees' satisfaction, government organization

\section{Introduction}

Job satisfaction is the positive feelings of employees towards the organization. Job satisfaction motivates employees' to be with the organization for long run and also acts as a part of the organization as family. People are the hearts of every successful business that make things happen. It is one of the most popular and widely researched topics in the field of organizational psychology (P.E.Spector, 1997). Apart from managerial and technical aspects, employers can be considered as backbone of any industrial development. To utilize their contribution, they should be provided with good working conditions to boost their job satisfaction. Researchers reported that several different factors can influence employee satisfaction with their workspaces, including building design, air quality and temperature, noise and lighting, ability of employees to personalize their workspaces and workspace design and management etc. It is generally understood that unfavorable conditions of office environment can have negative influences on employees' satisfaction, cause health problems and increase short-term sick leave.

The study variables are based on selecting samples of government employments using questionnaire as a main tool to collect data from various government offices in Tangail city. The variables to be measured are: the government organization procedures and employees' satisfaction, how much the offices procedures effect at the employee's satisfaction and internal programs that lead to satisfaction of employees and its impact on their performance, dedication and achievements. 
Objective of the study:

i. To examine the various motivational factors that impact on government employee's satisfaction.

ii. Identify and discuss the various motivational factors and the extent to which they affect and influence service delivery performance in rural area.

iii. To recommend approaches that can be followed by the public sector in improving service delivery performance.

\section{Literature Review}

Job satisfaction is defined as "a pleasurable or positive emotional state resulting from the appraisal of one's job or job experiences" (E.Locke, 1976). It is also defined by Newstrom as "a set of favorable or unfavorable feelings and emotions which employees view with their work" (Davis, K., \& Newstrom, J., 1993). When people speak of employee attitudes, they often mean job satisfaction. Human capital is its most valuable resource, which provides the solid foundation needed to build long-term profitability and ongoing success of an organization. If people of the organization are satisfied towards their job or work than it helps organization to achieve their targeted goal. Job performance is directly related with the job satisfaction. Job satisfaction plays an important role to reduce employees' turnover and absenteeism. It indicates the feelings an employee has towards his or her job based on the evaluation of its characteristics (M. Shallu,Sehgal, 2012).

Job satisfaction depends on different issues which may be related with financial side or may not be like; job security, working conditions, working environment, promotion facility, career advancement, recognition of good work, relationship with co-workers, responsibility sharing, salary, medical and housing facility, fair recruitment, selection \& promotion practices, training \& development (T\&D) practices, company goodwill \& reputation, management style, compensation package, logistical support etc. Employee satisfaction is the satisfaction of employees with their jobs or the degree to which employees like their jobs (Weerasinghe, 2017). So, employees' satisfaction has become a major concern to the organizations for their survival and growth.

\section{The Methodology and Model}

The study is conducted by using Simple Random Sampling technique where we include more than 80 samples considering the employees of government Organization in Tangail city. A survey method was used for the study and the data were collected by a Demographic Information Questionnaire and Employees satisfaction Attitudes Scale. The questionnaire includes personal information, Work \& Work environment, Supervisor and Supervision, Rewards and Promotion, Participation and other things related with their satisfaction. Initially, Demographic Information Questionnaire and Education Attitudes Scale were administered to the employees of government organization of Tangail city of different position. To meet the objective of the study both Univariate and Bivariate methods have been applied. Cross-table analysis is performed to study the association between dependent and various independent variables.

\section{Results and Discussion}

Table 1. Cross tabulation for finding the association between employees' designation with their gender

\begin{tabular}{rcccc}
\hline & & \multicolumn{2}{c}{ Gender of the respondents } & Total \\
\cline { 3 - 5 } & & Female & Male & 9 \\
& & 3 & 6 & 16 \\
Fesignation of the respondents & Office Attendant & 0 & 16 \\
& Officer & 13 & 25 & 38 \\
\hline & Teacher & 0 & 17 & 17 \\
\hline
\end{tabular}

\section{Hypothesis:}

H0: There is no association between gender and designation of the govt. employees.

$\mathrm{H} 1$ : There is association between gender and designation of the govt. employees.

Table 2. Chi-square table for finding the association between employees' designation with their gender

\begin{tabular}{lccc}
\hline & Value & D.F. & P-Value \\
\hline Pearson Chi-square & 14.046 & 3 & 0.003 \\
\hline
\end{tabular}

\section{Comment:}

Here we see that, employees' gender and designation is significantly $(\mathrm{p}<0.05)$ associated. So, we may reject the null hypothesis. That is, there is an association between employees' gender and designation. 
Table 3. Cross tabulation for finding the association between genders of the employees with their company treat me well

\begin{tabular}{ccccccc}
\hline & & \multicolumn{2}{c}{ Company treat me well } & \multicolumn{2}{c}{ Total } \\
\cline { 3 - 6 } & & Agree & Disagree & Most agree & Neutral & \\
\hline Gender of the respondents & Female & 3 & 3 & 0 & 10 & 16 \\
& Male & 10 & 23 & 4 & 27 & 64 \\
\hline Total & & 13 & 26 & 4 & 37 & 80 \\
\hline
\end{tabular}

\section{Hypothesis:}

$\mathrm{H} 0$ : There is no association between gender and company treat me well of govt. employees.

$\mathrm{H}_{1}$ : There is association between gender and company treat me well of govt. employees.

Table 4. Chi-square table for finding the association between genders of the employees with their company treat me well

\begin{tabular}{cccc}
\hline & Value & D.F. & P-Value \\
\hline Pearson Chi-square & 3.382 & 3 & 0.336 \\
\hline
\end{tabular}

\section{Comment:}

From the analysis we found that, employees' gender and company treat me well is not significantly $(\mathrm{p}>0.05)$ associated. So, we may not reject the null hypothesis. That is, there is no association between employees' gender and company treat me well.

Table 5. Cross tabulation for finding the association between through work council able to participate with 'involve in the decision in working meeting

\begin{tabular}{|c|c|c|c|c|c|c|}
\hline & & \multicolumn{4}{|c|}{ Involve in the decision in working meeting } & \multirow[t]{2}{*}{ Total } \\
\hline & & Agree & Disagree & $\begin{array}{c}\text { Most } \\
\text { disagree }\end{array}$ & Neutral & \\
\hline \multirow{4}{*}{$\begin{array}{c}\text { Through work council able to } \\
\text { participate }\end{array}$} & Agree & 0 & 4 & 0 & 3 & 7 \\
\hline & Disagree & 0 & 6 & 4 & 6 & 16 \\
\hline & $\begin{array}{l}\text { Most } \\
\text { agree }\end{array}$ & 0 & 0 & 0 & 4 & 4 \\
\hline & Neutral & 9 & 35 & 3 & 6 & 53 \\
\hline Total & & 9 & 45 & 7 & 19 & 80 \\
\hline
\end{tabular}

\section{Hypothesis:}

$\mathrm{H}_{0}$ : There is no association between through work council able to participate and involve in the decision in working meeting of the govt. employees.

$\mathrm{H}_{1}$ : There is association between through work council able to participate and involve in the decision in working meeting of the govt. employees.

Table 6. Chi-square table for finding the association between through work council able to participate with involve in the decision in working meeting

\begin{tabular}{cccc}
\hline & Value & D.F. & P-Value \\
\hline Pearson Chi-square & 30.099 & 9 & 0.000 \\
\hline
\end{tabular}

\section{Comment:}

It is observed that, employees between through work council able to participate and involve in the decision in working meeting significantly $(\mathrm{p}<0.05)$ associated. So, we may reject the null hypothesis. That is, there is an association between through work council able to participate and involve in the decision in working meeting.

Table 7. Cross tabulation for finding the association between satisfactions of job with their well performed of the views \& policies

\begin{tabular}{|c|c|c|c|c|c|c|c|}
\hline & & \multicolumn{5}{|c|}{ Well performed of the views \& policies } & \multirow[b]{2}{*}{ Total } \\
\hline & & Agree & Disagree & $\begin{array}{l}\text { Most } \\
\text { agree }\end{array}$ & $\begin{array}{c}\text { Most } \\
\text { disagree }\end{array}$ & Neutral & \\
\hline \multirow{3}{*}{ Satisfaction of job } & Agree & 16 & 0 & 0 & 0 & 0 & 16 \\
\hline & Disagree & 15 & 4 & 0 & 4 & 0 & 23 \\
\hline & Neutral & 21 & 0 & 7 & 4 & 9 & 41 \\
\hline Total & & 52 & 4 & 7 & 8 & 9 & 80 \\
\hline
\end{tabular}

\section{Hypothesis:}

$\mathrm{H}_{0}$ : There is no association between satisfaction of job and well performed of the views and policies of the govt. employees. 
$\mathrm{H}_{1}$ : There is association between satisfaction of job and well performed of the views and policies of the govt. employees.

Table 8. Chi-square table for finding the association between satisfactions of job with their well performed of the views \& policies

\begin{tabular}{cccc}
\hline & Value & D.F. & P-Value \\
\hline Pearson Chi-square & 32.205 & 8 & 0.000 \\
\hline
\end{tabular}

\section{Comment:}

From the above table we can see that, between satisfaction of job and well performed of the views and policies significantly $(\mathrm{p}<0.05)$ associated. So, we may reject the null hypothesis. That is, there is an association between satisfactions of jobs and well performed of the views and policies.

Table 9. Cross tabulation for finding the association between employees' satisfaction of job with their enough opportunities for financial growth in the organization

\begin{tabular}{ccccccc}
\hline & & \multicolumn{2}{c}{ Enough opportunities for financial growth in the organization } & \multirow{2}{*}{ Total } \\
\cline { 2 - 6 } & Agree & Disagree & $\begin{array}{c}\text { Most } \\
\text { disagree }\end{array}$ & Neutral & & \\
\hline \multirow{3}{*}{ Satisfaction of job } & Agree & 7 & 0 & 0 & 9 & 16 \\
& $\begin{array}{c}\text { Disagree } \\
\text { Neutral }\end{array}$ & 0 & 10 & 0 & 13 & 23 \\
\hline Total & & 26 & 6 & 7 & 9 & 41 \\
\hline
\end{tabular}

\section{Hypothesis:}

H0: There is no association between satisfactions of job with their enough opportunities for financial growth in the organization of the govt. employees.

H1: There is association between satisfactions of job with their enough opportunities for financial growth in the organization of the govt. employees.

Table 10. Chi-square table for finding the association between employees' satisfaction of job with their enough opportunities for financial growth in the organization

\begin{tabular}{cccc}
\hline & Value & D.F. & P-Value \\
\hline Pearson Chi-square & 33.428 & 6 & 0.000
\end{tabular}

\section{Comment:}

From the above analysis, we observe that satisfaction of job with their enough opportunities for financial growth significantly $(\mathrm{p}<0.05)$ associated. So, we may reject the null hypothesis. That is, there is an association between satisfactions with job with their enough opportunities for financial growth.

Table 11. Cross tabulation for finding the association between employees' satisfaction of job with their give good salary compared to similar organization

\begin{tabular}{ccccccc}
\hline & \multicolumn{4}{c}{ Give good salary compared to similar organization } & Total \\
\cline { 3 - 6 } & & Agree & Disagree & Most agree & Neutral & \\
& Agree & 4 & 3 & 0 & 9 & 16 \\
Satisfaction of job & Disagree & 4 & 13 & 0 & 6 & 23 \\
& Neutral & 18 & 3 & 8 & 12 & 41 \\
\hline Total & & 26 & 19 & 8 & 27 & 80 \\
\hline
\end{tabular}

\section{Hypothesis:}

H0: There is no association satisfaction with job with give good salary compared to similar organization of the govt. employees.

H1: There is association satisfaction with job with give good salary compared to similar organization of the govt. employees.

Table 12. Chi-square table for finding the association between employees' satisfaction of job with their give good salary compared to similar organization

\begin{tabular}{cccc}
\hline & Value & D.F. & P-Value \\
\hline Pearson Chi-square & 29.417 & 6 & 0.000
\end{tabular}

\section{Comment:}

Here we see that, between satisfaction with job with give good salary compared to similar organization significantly $(\mathrm{p}<0.05)$ associated. So, we may reject the null hypothesis. That is, there is an association between give good salaries compared to similar organization. 
Table 13. Cross tabulation for finding the association between employee's jobs is challenging and interesting with their enough opportunities for financial growth in the organization

\begin{tabular}{|c|c|c|c|c|c|c|}
\hline & & \multicolumn{4}{|c|}{$\begin{array}{c}\text { Enough opportunities for financial growth in the } \\
\text { organization }\end{array}$} & \multirow[t]{2}{*}{ Total } \\
\hline & & Agree & Disagree & Most disagree & Neutral & \\
\hline \multirow{4}{*}{$\begin{array}{l}\text { Job is challenging and } \\
\text { interesting }\end{array}$} & Agree & 17 & 0 & 0 & 16 & 33 \\
\hline & Disagree & 0 & 10 & 4 & 0 & 14 \\
\hline & Most agree & 6 & 0 & 0 & 6 & 12 \\
\hline & Neutral & 3 & 6 & 3 & 9 & 21 \\
\hline Total & & 26 & 16 & 7 & 31 & 80 \\
\hline
\end{tabular}

\section{Hypothesis:}

H0: There is no association between job challenging and enough opportunities for financial growth of the govt. employees.

H1: There is association job challenging and enough opportunities for financial growth of the govt. employees.

Table 14. Chi-square table for finding the association between employee's jobs is challenging and interesting with their enough opportunities for financial growth in the organization

\begin{tabular}{cccc}
\hline & Value & D.F. & P-Value \\
\hline Pearson Chi-square & 57.456 & 9 & 0.000 \\
\hline
\end{tabular}

\section{Comment:}

From the above table we found that, between job challenging and enough opportunities for financial growth are significantly $(\mathrm{p}<0.05)$ associated. So, we may reject the null hypothesis. That is, there is an association between job challenging and enough opportunities for financial growth.

Table 15. Cross tabulation for finding the association between employees' performance periodically reviewed with their give good salary compared to similar organization

\begin{tabular}{ccccccc}
\hline & & \multicolumn{2}{c}{ Give good salary compared to similar organization } & \multirow{2}{*}{ Total } \\
\cline { 3 - 6 } & & Agree & Disagree & Most agree & Neutral & \\
& Agree & 13 & 0 & 0 & 3 & 16 \\
Performance & Disagree & 3 & 10 & 0 & 9 & 22 \\
periodically reviewed & Most agree & 3 & 0 & 4 & 3 & 10 \\
& Most disagree & 0 & 0 & 0 & 6 & 6 \\
\hline & Neutral & 7 & 9 & 4 & 6 & 26 \\
\hline
\end{tabular}

\section{Hypothesis:}

H0: There is no association between performance periodically reviewed and give good salary similar organization of the govt. employees.

H1: There is association between job performance periodically reviewed and give good salary similar organization of the govt. employees.

Table 16. Chi-square table finding the association between employee's performances periodically reviewed with their give good salary compared to similar organization

\begin{tabular}{cccc}
\hline & Value & D.F. & P-Value \\
\hline Pearson Chi-square & 53.860 & 12 & 0.000 \\
\hline
\end{tabular}

\section{Comment:}

Here we see that, employees' performance periodically reviewed and give good salary significantly $(\mathrm{p}<0.05)$ associated. So, we may reject the null hypothesis. That is, there is an association between employees' performance periodically reviewed and give good salary.

Table 17. Cross tabulation for finding the association between employees' job department with their opportunity of flexible working hours

\begin{tabular}{lcccccrr}
\hline & & \multicolumn{5}{c}{ Opportunity of flexible working hours } & \\
\cline { 3 - 7 } & & Agree & Disagree & Most agree & Most disagree & Neutral & Total \\
\hline & Administration & 10 & 0 & 3 & 0 & 3 & 16 \\
& Bank & 0 & 16 & 0 & 3 & 0 & 19 \\
Job & Family Planning & 6 & 0 & 0 & 0 & 3 & 9 \\
department & Fisheries & 6 & 3 & 0 & 0 & 0 & 0 \\
& PDB & 3 & 0 & 7 & 0 & 0 & 10 \\
& Primary School & 0 & 10 & 4 & 0 & 3 & 17 \\
\hline & Total & 25 & 29 & 14 & 3 & 9 \\
\hline
\end{tabular}




\section{Hypothesis:}

$\mathrm{H}_{0}$ : There is no association between job department and opportunity of flexible working hours of the govt. employees.

$\mathrm{H}_{1}$ : There is association between job department and opportunity of flexible working hours of the govt.

Table 18. Chi-square table finding the association between employee's job departments with their opportunity of flexible working hours employees

\begin{tabular}{clcc}
\hline & Value & D.F. & P-Value \\
\hline Pearson Chi-square & 92.453 & 20 & 0.000 \\
\hline
\end{tabular}

\section{Comment:}

From the above table, we see that, employees job department and opportunity of flexible working hours significantly $(\mathrm{p}<0.05)$ associated. So, we may reject the null hypothesis. That is, there is an association between job department and opportunity of flexible working hours.

\section{Conclusion}

Every organization depends on their manpower for success and development. In-fact, if workers or employees work properly, the organization can easily achieve the target. To get the best out of the employees in work proper attention must be given to enhance their job satisfaction level. While studying the job satisfaction level of employees of different government organizations, the finding is that on average they were satisfied with their jobs (Sayed Mohibul Hossen, 2018). In this study, the aim is to identify the important factors for the job satisfaction of employees in a certain public institution and to what extent this institution satisfies the employees with respect to these prominent factors. The public institution, selected for this study is a central governmental institution, implementing fundamental economic policies and activities to contribute to the national economy and development of the social welfare. Job security should be given utmost importance, so that the employee's turnover may be restricted. If these factors are given little more care, the company can maintain good workers with high level of satisfaction, organizational commitment and involvement. This will in turn lead to effectiveness and efficiency in their work which leads to increased productivity. An organization should try to take every possible step to enhance job satisfaction among employees because if employees are satisfied then customers associated with it will also be satisfied.

\section{References}

Davis, K., \& Newstrom, J. (1999). Comportamiento Humano en el Trabajo: Comportamien to Organizaciona. 10th Edition, Mexico: McGraw-Hill. DeCenzo, D. A., \& Robbins, S. P., 2009. Fundamentals of Human Resource Management. 8th edition, Wiley India Pvt. Ltd., pp-34-43.

Locke, E. (1976). "The nature and causes of job satisfaction,” In M. D. Dunnette (Ed.), Handbook of industrial and organizational psychology, 1976 pp. 1297-1349). Chicago: Rand McNally.

M. Shallu,Sehgal, (2012). "Job satisfaction of bank employees”. International Journal of Marketing, Financial Services \& Management Research," 1(7), ISSN 2277, July 2012.

Sayed, M. H. (2018). Ridwana Chowdhury. Employees' Satisfaction of Government and Non-Government Banks in Tangail City, Bangladesh. Journal of Investment and Management, 7(2), 53-58.

Spector, P. E. (1997). “Job Satisfaction: Application, Assessment, Causes, and Consequences. Thousand Oaks, CA: Sage," 1997.

Weerasinghe. (2017). Factors Affecting to Job Satisfaction of Banking Employees in Sri Lanka. Business and Management Horizons, 5(1). https://doi.org/10.5296/bmh.v5i1.10987

\section{Copyrights}

Copyright for this article is retained by the author(s), with first publication rights granted to the journal.

This is an open-access article distributed under the terms and conditions of the Creative Commons Attribution license (http://creativecommons.org/licenses/by/4.0/). 